\title{
Assessment of behavior and feeding intake of dogs fed with soybean hulls
}

\author{
(Avaliação do comportamento e consumo de ração em cães alimentados com \\ casca de soja)
Mariana Scheraiber ${ }^{1 *}$, Tabyta Tamara Sabchuk ${ }^{1}$, Carolina Pedro Zanatta ${ }^{1,2}$, Tatiane Aparecida Ramos ${ }^{1}$, Ana Vitória Fischer da Silva ${ }^{1}$, Ananda Portella Félix ${ }^{1}$ \\ ${ }^{1}$ Universidade Federal do Paraná, Curitiba, Paraná, Brasil, ${ }^{2}$ VB Alimentos Ind. e Com. LTDA \\ *Corresponding author: marianascheraiber@gmail.com
}

\begin{abstract}
The diet composition can promote satiety and interfere in animal behavior. The aim of this study was to evaluate the behavior of dogs after ingestion of diet without soybean hull $(0 \% \mathrm{SH})$ and a diet with soybean hulls $(16 \% \mathrm{SH})$, as well as the daily consumption of food (supplied - leftovers) and metabolizable energy (ME) intake of diets. Twelve Beagle dogs were distributed completely randomly between two treatments, being six dogs consuming the $0 \% \mathrm{SH}$ diet and six dogs $16 \% \mathrm{SH}$ diet. The behavioral test consisted of observing the animals during 24 uninterrupted hours at intervals of 10 minutes at the end of 28 days of consumption of the diets. General behaviors were observed such as alert, scratching, stereotypical behavior, sleep, hygiene, walking, idle lying, idle standing, idle sitting and socialization. There was a reduction in scratching behaviors $(\mathrm{P}<0.05)$ and stereotypical behaviors $(\mathrm{P}<0.10)$ in animals that ingested the diet with $16 \% \mathrm{SH}$, in comparison to the animals that consumed $0 \% \mathrm{SH}$ diet. The consumption of the diets did not differ $(P>0.05)$, but the ME intake was lower $(P<0.001)$ in dogs that received a diet with $16 \% \mathrm{SH}$. The use of $16 \% \mathrm{SH}$ in the diet reduces the ME intake and undesirable behavior in dogs.
\end{abstract}

Key Words: animal nutrition, fibers, gastrointestinal physiology.

RESUMO: A composição da dieta pode promover saciedade e interferir no comportamento animal. O objetivo deste estudo foi avaliar o comportamento de cães após a ingestão de dietas sem casca de soja ( $0 \% \mathrm{CS}$ ) e com casca de soja (16\%CS), assim como o consumo diário de alimento (fornecido - sobras) e a ingestão de energia metabolizável (EM) das dietas. Doze cães da raça Beagle foram distribuídos inteiramente ao acaso em dois tratamentos, sendo seis cães consumindo a dieta $0 \%$ CS e seis cães a dieta $16 \%$ CS. O teste de comportamento consistiu em observação dos animais durante 24 horas ininterruptas em intervalos de 10 minutos ao final de 28 dias de consumo das dietas. Comportamentos gerais foram observados, como alerta, coçar, estereotipia, dormir, higienização, andar pela baia, ócio deitado, ócio em pé, ócio sentado e socialização. Houve redução nos comportamentos de coçar $(P<0,05)$ e estereotipia $(P<0,10)$ nos animais que ingeriram a dieta com $16 \% \mathrm{CS}$, com relação aos animais que consumiram a dieta $0 \% C S$. O consumo entre as dietas não diferiu $(P>0,05)$, porém a ingestão de EM foi menor $(P<0,001)$ nos cães que receberam a dieta com $16 \%$ CS. O uso de $16 \%$ CS na dieta reduz a ingestão de EM e comportamentos indesejáveis em cães.

Palavras-chave: fibras, fisiologia gastrointestinal, nutrição animal. 


\section{INTRODUCTION}

The dog's behavior can be influenced by diet effects on satiety, which is defined as the feeling of fullness and appetite disappeared after a meal. Dietary factors such as macronutrients, can influence it and some foods can be more effective than others in reducing hunger and begging behaviors, paw cleaning and coprophagy (Weber et al, 2008). Therefore, the search for alternatives to promote satiety is subject to investigation in order to assist with socialization and decrease undesired behaviors in companion animals. The diets for dogs can be studied according to their effectiveness in maintaining satiety after a meal and usually the diets provided have sufficient nutrients and energy to meet the daily needs of a dog (Bosch et al, 2009a).

$$
\text { Among the dietary }
$$

macronutrients, Bosch et al (2009b) indicated that the inclusion of fibers in the diets of dogs, depending on the type and level of inclusion, can prolong postprandial satiety. Soluble fiber sources, which are responsible for causing viscosity in the gastrointestinal tract (GIT), prolonging gastric emptying, slowing the absorption of nutrients and dilute dietary energy (Eastwood, 1992). On the other hand, insoluble fibers may also cause satiety in dogs due to gastric distension, cholecystokinin release and subsequent slowing of gastric emptying (Weber et al, 2008).

Soybean hulls $(\mathrm{SH})$ are a coproduct released during the initial phase of the soybean oil production. $\mathrm{SH}$ has a great potential to be used as a functional ingredient due to its high content of dietary fiber, including pectin and cellulose (Kim et al, 2015).

The rate and place of the foods digestion determines the postprandial physiological state of the animal and thus, the extent and duration of satiety and therefore the behavior. The physical and chemical composition of the fiber sources results in differences in satiety and the delay in hunger signals. Soluble fibers (SF) increase the volume and weight of the stomach contents and can stimulate the release of hormones related to satiety (Bosch et al., 2007). In a study of rats supplemented with fermentable fiber, Wren et al. (2001) found a decrease in plasma levels of ghrelin, hormone associated with signals of hunger and appetite in humans. Insoluble fibers (IF), can increase the volume of the stomach and intestines, helping to promote satiety (Lourenço, 2007), by means of theory of stomach distention. According to Case et al. (1998), gastric and intestinal distention stimulates the vagus nerve to send satiety signals to the central nervous system.

This study aimed to evaluate the daily dry matter intake and metabolizable energy (ME), as well as dog behavior after eating diets without soybean hulls $(0 \% \mathrm{SH})$ and containing $16 \%$ soybean hulls $(16 \% \mathrm{SH})$.

\section{MATERIAL AND METHODS}

\section{Animals and facilities}

Twelve Beagle dogs (6 males and 6 females) with an average weight of $11.3 \pm 1.6 \mathrm{~kg}$ and 4 years old were distributed in a completely randomized design and divided into two groups: $0 \% \mathrm{SH}$ and $16 \% \mathrm{SH}$. The dogs underwent clinical evaluations, which proved their good health, were vaccinated, dewormed and individually housed in brick stalls with a solarium (5 meters long $\times 2$ meters wide).

Diets

Two extruded diets were formulated: control $(0 \% \mathrm{SH})$ and test $(16 \% \mathrm{SH})$. The soybean hulls were included as a replacement for corn (table 1). The diets were fed to the dogs twice a day in fixed schedule, at 08:00 
am and 16:00 pm for 28 days. $0 \%$ SH diet was offered in sufficient quantity to meet the ME needs of dogs in maintenance, according to the NRC (2006): $\mathrm{kcal} /$ day $=130 \times$ weight (kg) 0,75 . The provision of the $16 \% \mathrm{SH}$ diet was calculated as a function of the value of ME to the $0 \% \mathrm{SH}$ diet. This calculation was used to only restrict energy, allowing the dogs to ingest the same volume of food in grams, of diet $0 \% \mathrm{SH}$. Water was provided ad libitum.

The diets were analyzed for dry matter content, crude protein, ether extract, crude fiber, total dietary fiber, soluble fiber, insoluble fiber, mineral matter, calcium and phosphorus, according to AOAC (1995). The ME content of diets was obtained in in vivo trial, with the same dogs in a previous experiment (Sabchuk et al., 2014), by the method of total feces collection and no urine collection (AAFCO, 2004).

Table 1 - Ingredients and chemical composition of the experimental diets.

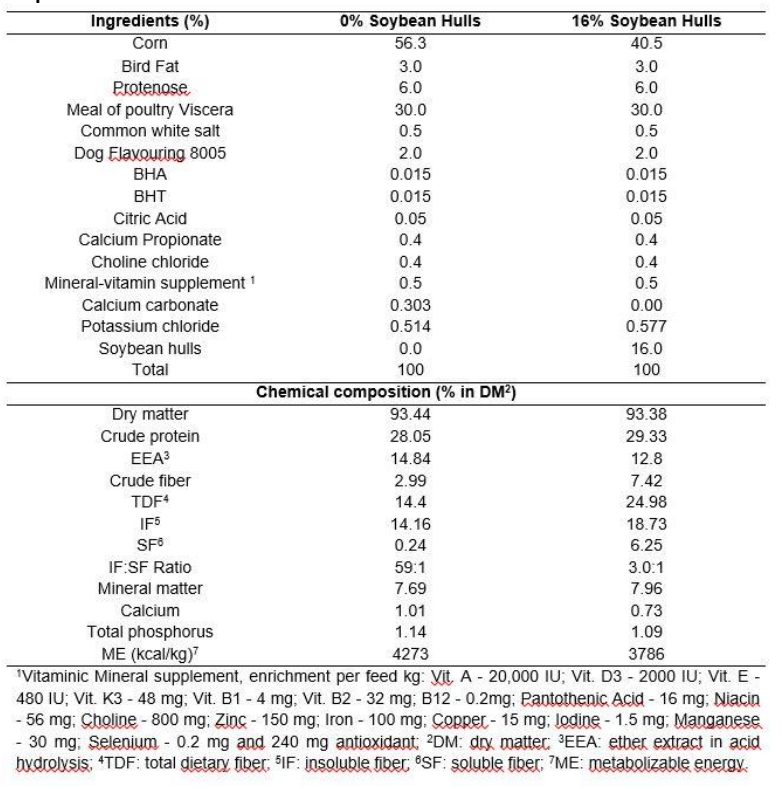

\section{Behavioral evaluation and food intake}

The dogs behavior was assessed after 28 days of consumption of the diets for 24 uninterrupted hours with intervals of 10 minutes in each observation and was expressed in frequency (\%) of occurrence (number of behavior observations/total number of observations $x$ 100). The following behaviors were recorded: Alert (attentive to movements), scratching, stereotypic behavior (repetitive regular movements, which are morphologically identical and with no obvious function), sleep (lying down in a ventral or lateral decubitus position with closed eyes), cleaning (fur cleaning), walking around the kennel, idle lying (ventral or lateral decubitus position with open eyes), idle sitting (leaning on the stretched front legs and flexed hind legs), idle standing (on 4 feet), and socialization (interaction with other animals in nearby kennels). Also, their daily food consumption was assessed (supplied - leftovers) and the ME intake of the diets.

\section{Statistical analysis}

The frequencies (\%) of the observed behaviors were analyzed using the Mann-Whitney-Wilcoxon test, with $\mathrm{P}<0.10$ indicating significant difference. The food intake data was analyzed by Student's t-test at $5 \%$ probability. The treatments had a total of six repetitions each.

\section{RESULTS AND DISCUSSION}

Fibers are structural carbohydrates derived primarily from plants cell wall. When combined with protein, fibers help regulate satiety levels in dogs (Koppel et al., 2015) and help to reduce the behavioral side effects in dogs, such as motivation of search for food. This is due to the prolongation of satiety that these diets can cause in the animal. The rate and nutrient degradation place largely determine the postprandial physiological response of the animal as well as the extent, duration of satiety and, therefore, the behavior (Bosch, 2009b).

Specific components or physicochemical properties of the fibers are important factors that influence the behavior and activity of the animal 
(Rijnen et al., 2003). In this study, we used the $\mathrm{SH}$ fibrous component added to the diet, which mainly presents insoluble fiber in its composition (ratio insoluble fiber: soluble 9,0:1). Cole et al. (1999) when studying different sources of $\mathrm{SH}$ found similar results (ratio insoluble fiber: soluble between 15.4:1 to $5.0: 1)$.

The effect of the fiber to stimulate and extend satiety depends on its properties and level of inclusion. Palumbo (2009) noted in their study that the supply of diets with SF to the dogs were more effective in inducing satiety in regard to IF. Firstly, the SF may increase the weight and volume of gastric contents, which can stimulate stretch receptors responsible for inducing gastric satiety signals. Secondly, gastric emptying may also be affected directly by SF causing intragastric viscosity or indirectly, by stimulating the release of glucagon-likepeptide-1, a potent inhibitor of gastric emptying (Bosch et al., 2007). Similarly, Smith (2013) found no satiety response in dogs fed rations supplemented with IF. Ninety minutes after consuming the entire energy needs of dogs for their maintenance, the author noted that, when exposed to palatable commercial food, the dogs ate a lot of the diet without signs of satiety and willing to swallow the food.

In this study, the animals fed the diet with $16 \% \mathrm{SH}$ had a lower intake of ME (table 2; $\mathrm{P}<0.001$ ) than animals fed the diet with $0 \% \mathrm{SH}$, however, there were no differences in consumption in grams $(P>0.05)$. In their studies, Bosch et al. (2009) confirmed that the inclusion of soybean hulls can help dilute the dietary energy and can be used as a source of fiber to dilute calories in diets for dogs. However, SF sources are more efficient in causing postprandial satiety in dogs. Butterwick et al. (1994) demonstrated that, physiologically, satiety or inhibition of food consumption result in ingestion consequences, namely the animal that had its hunger quenched after eating, had no food seeking behavior (time spent going the food bowl and number of visits to the feeder).

Table 2 - Average intake in grams/day and metabolizable energy (ME, kcal/day) in diets without soybean hulls $(0 \% \mathrm{SH})$ and with soybean hulls (16\%SH) for dogs.

\begin{tabular}{ccc}
\hline Treatment & Ingestion $(\mathrm{g})$ & Ingestion ME \\
\hline $0 \% \mathrm{SH}$ & 206.67 & 621.86 \\
$16 \% \mathrm{SH}$ & 205.00 & 518.44 \\
$\mathrm{SEM}^{1}$ & 4.344 & 16.878 \\
$\mathrm{P}^{1}$ value $^{2}$ & 0.858 & $<0.001$ \\
\hline
\end{tabular}

${ }^{1}$ SEM: Mean standard error; ${ }^{2} \mathrm{P}$ value: Significant differences if $\mathrm{P}<0.05$ among the averages by Student's t-test.

Bergeron et al. (2000) reported that the inclusion of the diet with oat hulls as fiber source promoted the reduction of stereotypic behavior in pigs, with a higher food consumption time and greater resting time, in comparison to the animals that received the diet without a source of fiber. These results are due to the source fiber used, which contains a large number of SF and has the capacity to absorb water from the GIT and become viscous, increasing satiety (Sueiro \& Mali, 2013).

In the present study, we observed a reduction in scratching behavior $(P<0.05)$ and stereotypical behavior $(P<0.10)$ in animals fed a diet with soybean hulls, the other behaviors evaluated did not differ $(P>0.05$; table 3).

This result agrees with those obtained by Bosch et al. (2007), which investigated diets with fiber sources (soybean hulls, beet pulp or oat hulls) and concluded that use of these sources of fibers can result in decreased stereotypical behavior, increased leisure time lying down and a decrease in aggressive behavior. The variability in physical and chemical properties of the fiber results in differences in satiety and the prevention of hunger behaviors and the biological mechanism of the 
properties of dietary fibers is not yet fully understood.

Table 3 - Average frequency of behaviors observed in dogs fed without soybean hulls $(0 \% \mathrm{SH})$ and with soybean hulls $(16 \% \mathrm{SH})$ in the diet.

\begin{tabular}{|c|c|c|c|}
\hline Behaviour & Treatments & Average (\%) & $P$ value ${ }^{1}$ \\
\hline \multirow{2}{*}{ Idle lying } & 0\%SH & 8.62 & \multirow{2}{*}{0.950} \\
\hline & $16 \% \mathrm{SH}$ & 8.97 & \\
\hline \multirow{2}{*}{ Idle sitting } & $0 \% \mathrm{SH}$ & 12.06 & \multirow{2}{*}{0.309} \\
\hline & $16 \% \mathrm{SH}$ & 13.10 & \\
\hline \multirow{2}{*}{ Idle standing } & 0\%SH & 4.83 & \multirow{2}{*}{0.300} \\
\hline & $16 \% \mathrm{SH}$ & 3.10 & \\
\hline \multirow{2}{*}{ Alert } & $0 \% \mathrm{SH}$ & 0.69 & \multirow{2}{*}{0.632} \\
\hline & $16 \% \mathrm{SH}$ & 1.38 & \\
\hline \multirow{2}{*}{ Sleeping } & 0\%SH & 52.06 & \multirow{2}{*}{0.222} \\
\hline & $16 \% \mathrm{SH}$ & 55.86 & \\
\hline \multirow{2}{*}{$\begin{array}{c}\text { Stereotypical } \\
\text { behavior }\end{array}$} & $0 \% \mathrm{SH}$ & 1.03 & \multirow{2}{*}{$0.100^{2}$} \\
\hline & $16 \% \mathrm{SH}$ & 0.00 & \\
\hline \multirow{2}{*}{ Socialization } & $0 \% \mathrm{SH}$ & 0.00 & \multirow{2}{*}{0.181} \\
\hline & $16 \% \mathrm{SH}$ & 0.69 & \\
\hline \multirow{2}{*}{$\begin{array}{c}\text { Self- } \\
\text { grooming }\end{array}$} & $0 \% \mathrm{SH}$ & 2.76 & \multirow{2}{*}{0.339} \\
\hline & $16 \% \mathrm{SH}$ & 2.07 & \\
\hline \multirow{2}{*}{ Scratching } & 0\%SH & 10.00 & \multirow{2}{*}{$0.006^{2}$} \\
\hline & $16 \% \mathrm{SH}$ & 6.21 & \\
\hline \multirow{2}{*}{$\begin{array}{l}\text { Walking in } \\
\text { the kennel }\end{array}$} & $0 \% \mathrm{SH}$ & 3.10 & \multirow{2}{*}{0.374} \\
\hline & $16 \% \mathrm{SH}$ & 3.45 & \\
\hline
\end{tabular}

However, many fiber sources have important characteristics in maintaining satiety, primarily by increasing the viscosity and weight of the food bolus in the GIT, by gastric filling and increased small bowel transit, providing increased contact between nutrients and intestinal receptors involved in maintaining satiety. Moreover, fibers may help regulate the digestive process and the glycemic response in dogs and cats. Depending on the type of fiber and the amount consumed, different effects on nutrient digestibility and fecal forming can be promoted (Koppel et al., 2015).

Agreeing to Lourenço (2007), many studies suggest that soluble fibers may be more efficient than insoluble ones when the goal is to promote satiety. In contrast, according to Sunvold et al. (1994), low fermentability fibers, such as cellulose and peanut hulls, and intermediate fermentability, such as soybean hulls increase stomach and intestine volume, helping to promote a feeling of satiety when few calories are consumed.

\section{CONCLUSIONS}

The inclusion of soybean hulls as a fiber source in the diet of beagle dogs decreased scratching and stereotypical behaviors, as well as metabolizable energy intake in the diet.

\section{BIOETHICS AND BIOSECURITY COMMITTEE APPROVAL}

All procedures in this study were performed in accordance to Registration Protocol CEUA/UFPR 019/2012 approved by the Ethics Committee on the Use of Animals of the sector of Agrarian Sciences at Federal University of Paraná, Curitiba, PR, Brazil.

\section{ACKNOWLEDGEMENT}

We would like to thank "VB Rações" for providing the diets.

\section{REFERÊNCIAS}

1. Association of American Feed Control Officials. Dog and Cat Nutrient Profiles. Official Publications of the Association of American Feed Control Officials Incorporated. Oxford, IN, USA: AAFCO, 2004.

2. Association of the Official Analytical Chemists. Official Methods of Analysis, 16 ed. Washington, DC, USA: AOAC, 1995.

3. BERGERON, R.; BOLDUC, J.; RAMONET, $Y$. et al. Feeding motivation and stereotypies in pregnant sows fed increasing levels of fibre and/or food. Applied Animal Behaviour Science. v.70, p.27-40, 2000.

4. BOSCH, G.; BEERDA, B.; HENDRIKS, W.H. et al. Impact of nutrition on canine behaviour: current status and possible mechanisms. Nutrition Research Reviews. v.20, p.180-194, 2007.

5. BOSCH, G.; BEERDA, B.; VAN DE HOEK, E. et al. Effect of dietary fibre type on physical activity and behavior in 
kenneled dogs. Applied Animal Behaviour Science. v.121, p.32-41, 2009a.

6. BOSCH, G. Can diet composition affect behaviour in dogs? Food for thought. 2009b. 152p. Ph.D. thesis, Wageningen University, the Netherlands.

7. BUTTERWICK,

R.F.; MARKWELL, P.J.; THORNE, C.J. Effect of level and source of dietary fiber on food intake in the dog. The Journal of Nutrition. v.124, p.2695S-2700S, 1994.

8. CASE, L.P.; CAREY, D.P.; HIRAKAWA, D.A. Nutrição canina e felina: manual para profissionais. Madrid: Harcourt Brace, 1998. 424p.

9. COLE J.T.; FAHEY G.C.; MERCHEN N.R. et al. Soybean Hulls as a Dietary Fiber Source for Dogs. Journal of Animal Science. v.77, n.4, p.917-924, 1999.

10. EASTWOOD, M.A. The Physiological effect of dietary fiber: an update. Annual Reviews Nutrition. v.12, p.19-35, 1992.

11. KIM, H.W.; LEE, Y.J.; KIM, Y.H.B. Efficacy of pectin and insoluble fiber extracted from soy hulls as a functional non-meat ingredient. LWT - Food Science and Technology. v.64, p.10711077, 2015.

12. KOPPEL, K.; MONTI, M.; GIBSON, M. et al. The Effects of fiber inclusion on pet food sensory characteristics and palatability. Animals. v.5, n.1, p.110-115, 2015.

13. LOURENÇO, L.M.A. Diferentes fontes de fibra suplementar em rações úmidas para cães. 2007. 44p. Dissertação (Mestrado em Zootecnia) Programa de Pós-Graduação em Zootecnia, Universidade Federal Rural do Rio de Janeiro.

14. PALUMBO, G.R. Efeito da ingestão de amido, fibra e energia na resposta glicêmica pós-prandial e saciedade em cães. 2009. 62p. Dissertação (Mestrado em Medicina Veterinária) - Curso de Pós-graduação em Medicina Veterinária (Clínica Médica), Universidade Estadual Paulista - Jaboticabal.

15. RIJNEN, M.M.J.A.; VERTSEGEN, M.W.A.; HEETKAMP, M.J.W. et al. Effects of dietary fermentable carboydrates on behaviour and heat production in group-housed sows. Journal of Animal Science. v.81, n.1, p.182-190, 2003.

16. SABCHUK, T.T.; SILVA, J.R.; MARX, F.O. et al. Effect of feeding frequency of a diet containing soya hulls on the food intake and behaviour of dogs. Journal of Nutritional Science. v.3, n.60, p.1-4, 2014.

17. SUEIRO, A.C.; MALI, S. Propriedades físico-químicas e funcionais da casca de aveia "in natura" e branqueada. Anais do III Simpósio de Bioquímica e Biotecnologia. Universidade Estadual de Londrina. v.2, p.253-256, 2013.

18. SUNVOLD, G.D.; FAHEY JR, G.C.; MERCHEN, N.R. et al. Fermentability of selected fibrous substrates by dog fecal microflora as influenced by diet. The Journal of Nutrition. v.124, p.2719-2720, 1994.

19. WEBER, M., BISSOT, T., SERVET, E., SERGHERAERT, R., BIOURGE, V., GERMAN, A.J. A highprotein, high-fiber diet designed for weight loss improves satiety in dogs. Journal of Veterinary Internal Medicine. v.21, n.6, p.1203-1208, 2007.

20. WREN, A.M., SEAL, L.J.; COHEN, M.A. et al. Ghrelin enhances appetite and increases food intake in humans. Journal of Clinical Endocrinology \& Metabolism. v.86, n.12, p.5992-5995, 2001 